\title{
Dinamika Hukum Islam dan Perubahan Sosial
}

\author{
Oleh Sidik Tono
}

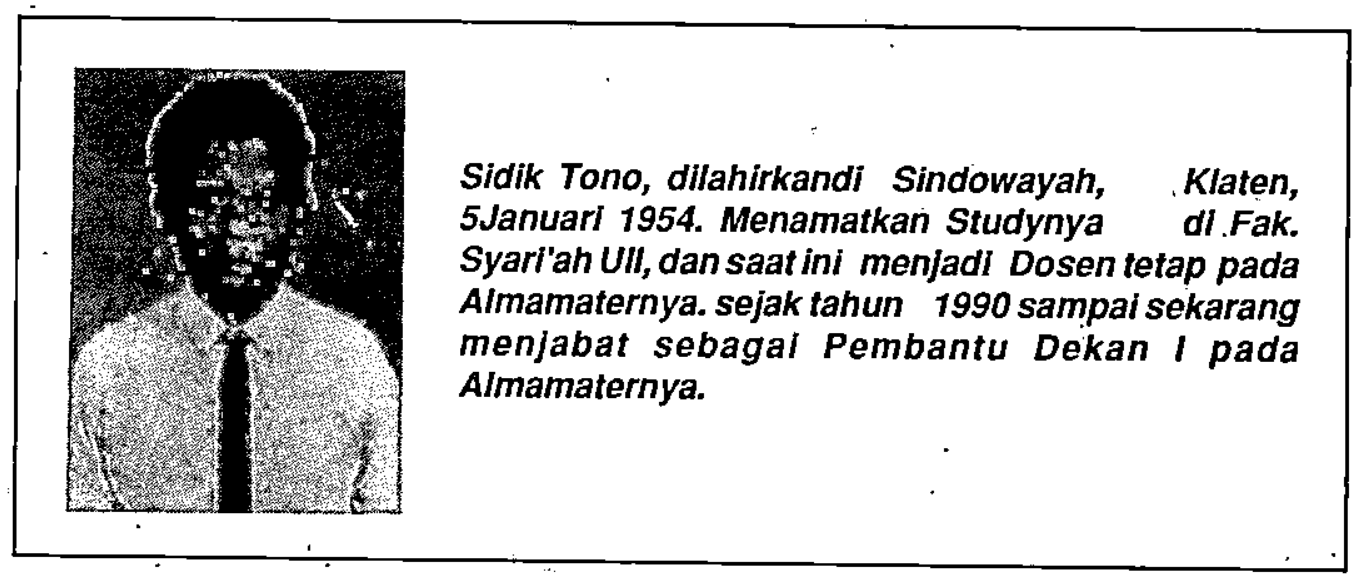

Pendahuluan

Dalam sejarah peradaban umat manusia selalu muncul fenomena yang mengarah pada adanya suatu perubạhan. Catatan sejarah menunjukkan bahwa perubahan sosial budaya selalu mempengaruhi tata kehidupan manusia. Umat Islam yang merupakan salah satu fenomena perubahan di atas ternyata pernah mengalami kemajuan "dalam bidang ilmu dan teknologi yang kemudian merupakan embrio kemajuan ilmu dan teknologi di abad modem ini. Satu aspek yang menjadi perhatian dalam tulisan ini adalah kenyataan bahwa perkembangan pemikiran hukum Islam yang terjadi pada waktu kemajuan Islam itu temyata sejalan dengan derap setiap perubahan sosial budaya yang dalam ilmu tasyri' disebut masa Imam Mazdhab ${ }^{2}$

Perkembangan ilmu dan teknologi dewasa ini terasa tajam menggebrak pemikiran hukum. Islam dalam skala yang cukupkompleks. Karena itu tuntutan ijtihad secara kreatif dan selektif semakin diperlukan dalam. menghadapi masalahmasalah baru yang timbul, tanpa menanggalkan identitas yang harus dipertahankan.

Hukum Islam merupakan hukum yang jangkauannya meliputi semua aspek kehidupan manusia sehingga untuk memahami hukum Islam perlu diketahui lebih dulu perbedaan syariah dan Fiqh (Hukum Islam).

Syari'ah adalah peraturan-peraturan Allah yang disampaikan melalui Nabi-nabi Nya yang tidak dapat di ubah dan diganti. Sedangkan Figh atau Hukum Islam adalah penafsiran atau pemahaman para ulama

1.) Awal abad kedua hijriah sampai pertengahan abad keempat hijriah.

2.) Dr. Abdul Karim Zaidan, AlMadkhal lidirasah as syari'ah al/slaniyah, (Darul Umar bin al Khattab), hal 141 
atau fuqaha terhadap hukum-hukum Syari'ah $^{3}$ baik secara tekstual maupun kontekstual. Jadi hukum Islam dapat menerima perubahan sejarah dengan perkembangan tempat dan waktu.

Tujuan Syari'ah adalah untuk kemashlahatan umat manusia. ${ }^{4}$ Syari'ah itu dicanangkan demi kebahagiaan manusia lahir maupun batin, dunia dan akhiraat, sehingga penempatan mashlahat sebagai acuan Syari'at adalah semata-mata untuk memenuhi tujuan di atas. Dalam konteks pengembangan hukum Islam pun pada dasamya tidak boleh menyalahi tujuan Syari'at di atas.

Dalam kaitan ini dapat disebutkan sebagai contoh bagaima khalifah Umartelah memformulasikan tujuan Syari'at itu. Salah satu hasil ijtihad khalifah Umar adalah tidak membagi habis tanah fai-i (rampasan perang) yang luas dan subur kepada para tentara, Alasan Umar adalah agar tanah taklukan itu tetap digarap oleh rakyat setempat dengan ketentuan mereka harus membayarkharaj (retibusi) tertentu kepada - negara, tujuannya adalah agar rakyat takluk tidak perlu kehilangan mata pencaharian dan tetap bisa bckerja untuk memenuhi kebutuhan hidup mereka sendiri dan keluarganya, sclain itu kharaj (retribusi) yang dibayarkan oleh rakyat taklukan scbagai imbalan atas hak menggarap tanah tersebut negara memperoleh income yang dapat digunakan untuk menggaji dan memberi tunjangan kepada tentara yang telah berjuang tersebut. ${ }^{\mathrm{s}}$

Kecerdasan dan kreativilas Umar , untuk mengkaji jiwa yang tcrsimpan di dalam Syari'at itu ternyata mendapat tantangandari bebcrapasahabat Nabi scperti Bilal bin Abi Rabah yang menyatakan bahwa ijtihad Umar itu telah mengabaikan suatu ketentuan yang secara eksplisit termaktub dalam al Qur'an dan Sunnah. Alasan penentangan tersebut karena ketentuan harta rampasan itu telah disebut dengan jelas di dalam al Qur'an surat al Hasyr ayat 7 berbunyi; ${ }^{6}$

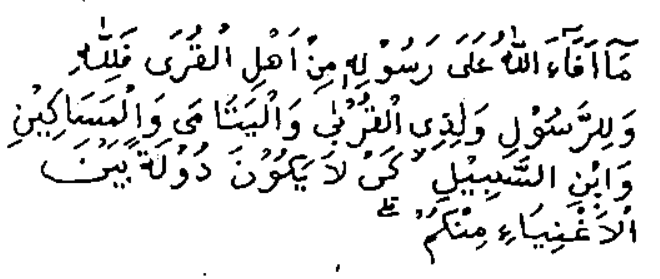

Artinya : Apa saja harta rampasan (fai'i) yang diberikan Allahkepada Rosulnyayang berasal dari penduduk kota-kota, maka adalah untuk Allah, Rosul, kerabat Rosul, anak-anak yatim, orang-orang miskin dan orang-orang yang dalam perjalanan, supaya harta itu jangan beredar di antara orang-orang kaya saja di antara kamu.

Jika diperhatikan kedua pandangan tersebut terlihat bahwa Hujjah lafzdiyah (tekstual) itu memang kuat, akan tetapi dengan mengajukan Hujjah maknawiyah (substansial- mashlahat) Umar merasa jauhlebih kuat.

\section{Konstruksi Metodologi Hukum Islam}

Dari uraian diatas terlihat bahwa sebenamya konstruksi dasar pembinaan hukum Islam telah dilctakkan oleh Rosulullah saw yang bentuk-bentuk cakupan hukum yang diformulasikannya dapat berupa; pertama penjelasan yang

3.)Dr. Farouq Abu Znid, As Syariah al Islamiyah baina Mulafidhin wa al Mujaddidin (diterjemnlikan oleh H. Husein Mulıammad), hal. 17

4.) Prof. Dr. H. lsmail Muhammad Syah, SH, Filsafat Hukum Islam, (Jakara : Bumi Aksara, 1992), hal. 65

5.) Masdar F. Mas'udi. Meletakkan kembali Maslahat sebagai acuan Syari'al, (Jakar1a : 1992), hal. 1

6.) QS. al Hasyr (59) : ? 
berkaitan dengan arti dan maksud seperti pengertian "shalat" dalam perintah al Qur'an yangkemudian dijelaskan oleh Nabi dengan contoh dan perbuatan; kedua penjelasan yang berkaitan dengan perluasan dasardasar yang dinyatakan al Qur'an yang kelihatannya menambah hukum yang dinyatakan Allah dalam al Qur'an itu sendiri, seperti yang terlihat dari sabda Nabi saw yang menyatakan mahram karena susuan adalah sebagaimana mahram karena hubungan kekerabatan. Ini berarti memperluas mahram susuan, padahal sebenarnya mahram . susunan yang dinyatakan al Qur'an itu ada dua yaitu ibu tempat menyusu dan saudara sepersusuan; ketiga penjelasan yang berkaitan dengan pembatasan ataú pengurangan keluasan kandungan al Qur'an. Hal ini terlihat dari penjelasan Nabi yang mempersempit pelaksanaan hukum, seperti penjelasan Nabi yang menyatakan bahwa si pembunuh tidak mendapat warisan dari orang yang dibunuhnya ${ }^{7}$

Tiga hal esensial diatasmenunjukkan betapa dinamisnya konstruksi dasar pembinaan hukum Islam yang diperlihatkan oleh Rosulullah yang ternyata mempunyai sifat yang kokoh, kuat, luwes dan elastis dalam menerima perubahan keadaan yang dihadapinya.

Dari cara konstruksi Nabi tersebut di atas, kemudian para ulama mulai menyusun konstruksi metodologi untuk menafsirkan ayat-ayat dan hadits dalam usaha untuk mendekatkan pemahaman kepada maksud dan tujuan syari'at dan usaha untuk mendekatkan hasil penalaran atau pemahaman tersebut dengan kenyataan sosial yang berkembang di tengah-tengah masyarakat.

Konstruksi sistematis metodologi tersebut mula-mula diperkenalkan oleh Imam Syafi'i $(150-204 \mathrm{H}) .{ }^{8}$ sehingga para ulama semasa dan sesudahnya cenderung memanfaatkan dan mempertahankan, dan hanya dalambeberapa bagian saja mereka mengadakan pengembangan danperubahan atasnya.

Konstruksi hukum Islam itu secara garis besar dapat dibagi menjadi tiga pola yaitu : (1) pola bayani (kajian semantik); (2) pola tálili (penentuan illat-faktoral); (3) pola istislahi (pertimbangan kemaslahatan). ${ }^{9}$ Pola pertama lebih menitikberatkan pada kajian bahasa(semantik) seperti kapan suatu lafadz itu berarti hakiki atau majaz. Bagaimana cara memilih salah satu arti dari lafads musytarak, mana ayat yang qath'i serta mana ayat dzanni dan sebagainya dibahas dalam ilmu Usul Fiqh secara rinci. Pola kedua adalahpola ta'lili yakni pola yang lebih menitikberatkan pada kajian penentuan illat (penentuan faktor yang menjadi tambatan hukum) yang secara prosedur dibahas cara-cara menentukan illat, syarat-syarat illat, penggunaan illat dalam qiyas serta perubahan hukum jika kemudian ditemukan illat yang baru.

Pola ketiga adalah pola istislahi, suatu pola yang lebih menitik beratkan pada pertimbangan maslahat, maksudnya adalah kajian yang berhubungan dengan masalahmasalah baru yang biasanya muncul karena adanya kemajuan ilmu dan teknologi.

Konstruksi metodologi hukum Islam yang ditawarkan para ulama dan yang dipelopori oleh Imam Syafi'i itu dalam pelaksanaannya sepenuhnya mewakili

7.) Hadits Nabi

8.) Ari Ansori (peny.), Figh Indonesia dalam tantangan, (Surakarta : FIAI - UMS, 1991), hal. 13.

9.) Ibid 
logika pemikiran hukum Islam sebagai proses pelacakan hukum yang paling standar yang telah diterima oleh semua mazhab. Hanya saja adanýa kemajuan ilmu dan teknologi yang menyebabkanterjadinya perubahan sosial dewasa ini sering pula menimbulkan kesulitan dalam menerapkan prosedur yang baku diatas, sehingga ditawarkan modus penyangga yakni pola istilahi, seperti Maslahah Mursalah dari Imam Malik dan Istihsan dari Imam Hanafi. Di dalam Ușhul Fiqh polà ini sangat sedikit mendapat perhatian, meskipun secara embrional telah diperkenalkanoleh khalifah Umar dalam contoh diatas.

\section{Hukum Islam dan Perubahan Sosial.}

Konstruksi metodologi hukum Islam diatastidak lain adalah suatu model analisis untuk menentukan hukum sekaligus menampakkan hakekat tujuan Syari'at dalam rangka kemaslahatan manusia. Dalam kondisi sosial budaya yang terus berubah ini tentunya maslahat selalu menjadi acuan Syari'at, dengan konstruksi metodologi hukum Islam tujuan Syari'at yang dapat ditentukan. Sebagai contoh dalam nash didapati bahwa zakat tanaman ada tiga jenis yaitu gandum, kurma dan anggur. Kemajuan ilmu dan teknologi itu temyata mempengaruhi perubahan sosial budaya masyarakat bahwa jenis tanaman diasas tidak hanyatiga. Pelacakan hukum mengenai jenis tanaman lain yang wajib dizakati, berarti berupaya untuk mencari illat hukum. Perhatian sebagaian besar para ulama dalam mencari illat dari tiga jenis tanaman diatas selanjutnya memperluas kepada jenis tanaman yang lain yang mempunyai illat sejenis. Ada yang menyatakanbahwa illatnya adalah tahan disimpan lama, ada juga yang menyatakan mengenyangkan (makanan pokok); bijibijian ditanam (bukan tumbuh sendiri); dan ada pendapat yang terakhir dari Yusuf Qardhawi 'bahwa "pembudidayaanlah" sebagai illatnya. ${ }^{10}$

Karena itu mengenai kewajiban mengeluarkan zakat untuk tanaman lain seperti kopi, cengkih, rotan dan lain sebagainya terdapat perbedaan pendapat, ada yang menyatakan terkena zakat, ada yang`menyatakan tidak, tergantung mana illat yang dipilih. Menurut penulis, jika terjadi perbedaan karena beda dalam memilih illat, maka kemaslahatan manusia menjadi ukuran. Dengan demikianillat yang dipakai adalah yang lebihkuat maslahatnya di antara illat-illat yang lain. Hal ini berarti pula bahwa faktor kenyatan sosial budaya mempunyai saham sebagai tendensi penalaran untuk menèmukan hukum.

Dalam kaitannya dengan perubahan sosial budaya yang terus bergerak karena pengaruh kemajuan ilmu dan teknologi, - menuruthemat saya konstruksi metodologi hukum Islam sampai saat ini masih efektif untuk digunakan sebagai metodologi penalaran hukum, artinya pola ta'lili digunakan apabila dirasa pola bayani kurang menjangkau tujuan syari'at. Demikian juga pola istislahi baru digunakan jika kedua pola diatas kurang menjangkau tujuan syari'at. Akan tetapi pola istislahi ini pada dasarnya hanya akan mampu menjangkau masalah-masalah yang tidak pasti (masalah kontemporer), yang memang harus diijtihadi terus menerus sesuai dengan tuntutan ruang dan waktu serta perubahan sosial budaya yang terus bergerak, yakni;

10.) Yusuf al Qardhawi, Figh al Zakah, jilid 1, (Beirut : Mu'assasah al Risalah, 1980), hal. 350 
selalu mengkaji definisi kemaslahatan dalam konteks ruang dan waktu adalah relatif dimana kita berada; selalu mengkaji kerangka kemaslahatan normatif yang memadai sebagai perwujudan dari cita kemaslahatan dalam konteks ruang dan waktu tertentu; dan selalu mengkaji kerangka kelembagaan yang memadai bagi sarana aktualisasi norma-norma kemaslahatan dalam realitas sosial yang bersangkutan. ${ }^{11}$, seperti kajian masalahmasalah baru yang muncul di Indonesi antara lain, NKKBS, bedah plastik. penggantian kelamin, bursa efek, transplantasi organ tubuh, dan laïn sebagainya yang sepertinya muncul sejalan dengan perkembangan ilmu dan teknologi.

Dalam rangka mengaktualisasikan penalaran hukum agar sejalan dengan perubahan sosial budaya, menurut $\mathrm{Dr}$. Al Yasa Abu Bakar ${ }^{12}$ persoalan utamanya adalah bahwa pengembangan dan perubahan itu tidak terletak pada "pola penalaran" perangkat lunak) dan tidak juga pada "al Quran" dan Sunnah (perangkat kerasnya), melainkanlebih banyak terletak pada kualitas mujtahid (operator) dan keberaniannyauntuk bereksperimen. Yang dimaksud kualitas itu adalah penguasaan ilmu-ilmu pendukung seperti bahasa Arab, Ushul Fiqh, al Quran dan al Hadits serta penguasaan ilmu-ilmu modern (pengembangan) yang diperlukan seperti Sosiologi Pssikologi untuk hukum keluarga dan lain-lain. Sedang eksperimen dapat dicontohkan dengan pernyataan untuk menggugat kemapanan dengan menggunkän kaidah baru yang sebelumnya tidak pernah digunakan.

\section{Daftar Pustaka}

Dr. Abdul Karim Zaidan, Al Madkhal lidirasah al Syari'ah al Islamiyah. (Darul Umar bin al Khattab).

Ari Ansori (peny.), Fiqh Indonesia dalam tantangan, (Surakarta : FIAI-UMS, 1991).

Departemen Agama RI, AlQur'an dan terjemahnya, (Jakarta : CV. Kathoda, 1990).

Dr. Farouq AbuZaid, Al Syari'ah al Islamiyah baina alMuhafizin wa al Mujaddidin, (diterjemahkan oleh H. Husein Muhammad), (Jakarta : Perhimpunan Pengembangan Pesantren dan' Masyarakat, 1988).

Prof. Dr. H. Ismail Muhammad Syah, SH; Filsafat Hukuın Islam, (Jakarta: Bumi Aksara, 1992).

Sidik Tono, Hukum Islam dan Konstelasi Ruang dan Waktu, (Yogyakarta : artikel yang dalam harian surat kabar "Yogya Post" hari Jum'at, 8 Juni 1990).

Dr. Yusuf al Qardhawi, Fiqh al Zakah, jilid 1, (Beirut: Mussasah al Risalah, 1980)

11) Masdar F. Mas'udi, Op cit, hal. 6

12.) Ari Ansori (peny.), Op cit, hal. 16. 